\title{
PERSPECTIVE AND ESSENCE OF ACHIEVEMENT MOTIVATION TO PURSUE LEARNING OUTCOMES
}

\author{
Wahyudi \\ Tanjungpura University
}

\begin{abstract}
The dimensions of students' achievement consist of various factors. These factors include completeness of school infrastructure, attention from parents, study habits, and achievement motivation. From several studies conducted by researchers in the field of education, it was found that achievement motivation factors had a greater contribution than other factors. Therefore, a teacher needs to know the needs of students to pursue their learning achievement. With this good understanding, the teacher can look for various efforts to grow motivation in accordance with the diversity or characteristics of the students.
\end{abstract}

\section{Keywords: Achievement motivation, Learning outcomes}

\section{PENDAHULUAN}

Dalam berbagai kajian dan fakta-fakta empirik diakui bahwa kebutuhan dapat menyebabkan adanya dorongan internal yang menggerakkan seseorang melakukan suatu ke arah tercapainya tujuan. Tenaga pendorong atau penarik yang menyebabkan adanya tingkah laku ke arah suatu tujuan tertentu disebut motivasi (Morgan, 1986). Hal senada dikemukakan oleh Wlodkowski (dalam Suciati, 1994) mendefinisikan motivasi sebagai suatu kondisi yang menyebabkan atau menimbulkan perilaku tertentu dan yang memberi arah dan ketahanan (persistence) pada tingkah laku tersebut. Tidak berbeda dengan dua pendapat di atas, Koontz, O'Donnell, dan Weihrich, (1986) mengartikan motivasi sebagai suatu keadaan di dalam diri seseorang (inner state) yang mendorong, mengaktifkan, atau menggerakkan dan yang mengarahkan atau menyalurkan perilaku ke arah tujuan. Motivasi dipandang sebagai tenaga pendorong kegiatan seseorang, sedangkan faktor pendorong aktivitas seseorang dapat berasal dari dalam dan dari luar.

Motivasi yang berasal dari dalam diri seseorang disebut motivasi intrinsik.
Sedangkan motivasi yang datangnya dari luar diri seseorang disebut motivasi ekstrinsik.

Dalam berbagai perspektif kajian diungakpkan motivasi merupakan keadaan batin seseorang yang mendorong dan mengarahkan perilaku ke arah tujuan. Seseorang akan termotivasi melakukan pekerjaan untuk mencapai sasaran yang dianggap lebih berharga, maka ia akan berusaha secara maksimal demi tercapainya tujuan yang diinginkan. Dalam konteks pendidikan di sekolah, maka siswa akan belajar di sekolah dengan tekun, mengerjakan tugas yang diberikan guru secara sungguh-sungguh, hadir di sekolah sebelum jam pelajaran dimulai, berdiskusi dengan teman-teman di kelas, memanfaatkan waktu luang untuk membaca buku diperpustakaan, dan berusaha memiliki buku yang dianjurkan oleh guru.

Teori-teori Motivasi. Peran teori di dalam menuntun berpikir seseorang sangat besar. Teori dapat membimbing seseorang dalam menganalisis dan menyelesaikan persoalan. Dikemuka-kan oleh Winardi (1990), kekuatan terbesar sebuah teori terletak pada manfaatnya sebagai sebuah model umum untuk 
menghadapi aneka macam problema. Teori dapat mengatasi keraguan terhadap suatu penyelesaian masalah dan meyakinkan pada rencana tindakan yang akan dilaksanakan. Walaupun teori-teori tentang motivasi tidak dapat memberikan petunjuk bagaimana seorang harus berperilaku dalam situasi tertentu, namun teori merupakan petunjuk bagi langkah-langkah yang perlu dipertimbangkan dalam pengambilan keputusan. Teori dapat menunjukkan proses yang paling mungkin memperoleh hasil yang diinginkan.

Dalam proses pembelajaran, siswa akan belajar dengan baik kalau mereka memiliki motivasi yang tinggi dalam pelaksanaan tugasnya. Dengan demikian, motivasi belajar sebagai kondisi yang mempengaruhi, mengarahkan, dan memelihara perilaku siswa untuk penyelesaian tugas-tugas belajar yang diberikan guru.

Maslow mendasarkan konsep hirarki kebutuhan atas dasar dua prinsip. Pertama, kebutuhan-kebutuhan manusia dapat disusun dalam suatu hirarki dari kebutuhan terendah sampai yang tertinggi. Kedua, suatu kebutuhan yang telah terpuaskan menjadi motivator utama bagi perilaku berikutnya. Dalam teori ini, manusia akan terdorong untuk memenuhi kebutuhan yang paling kuat sesuai dengan keadaan dan pengalaman masing-masing mengikuti suatu hirarki. Terdapat lima tingkatan kebutuhan dalam diri seseorang mulai dari yang paling dasar sampai pada tingkatan tertinggi, yaitu kebutuhan jasmaniah (Psysiological), kebutuhan memperoleh rasa aman, kebutuhan sosial, kebutuhan memperoleh harga diri, dan kebutuhan aktualisasi diri. Setelah kebutuhan pertama tercapai, kebutuhan yang lebih tinggi berikutnya akan menjadi kebutuhan utama, yaitu kebutuhan keamanan dan rasa aman (Safety and security). Kebutuhan ketiga akan muncul setelah kebutuhan terpenuhi. Proses ini berjalan terus sampai terpeunhinya kebutuhan aktualisasi diri (Self-Actualization). Akan tetapi seseorang akan merasa kecewa, tertekan, dan timbul konflik pada dirinya jika kebutuhannya tidak terpenuhi sehingga tidak bersemangat dalam belajar.

Realitas menunjukkan bahwa setiap individu mempunyai tingkat kebutuhan yang berbeda-beda sesuai dengan keadaan dan cita-citanya. Dikemukakan oleh Graves (Hersey dan Blanchard, 1986), manusia hidup pada tingkatan yang berbeda sesuai dengan kemampuan dalam mencapai kebutuhan. Orang pada tingkatan hidup tertentu memiliki perilaku dan nilai-nilai yang bercirikan sesuai dengan tingkatan hidupnya. Sebagaimana diungkapkan oleh Stoner dan Freeman (1992) bahwa Alderfer sepakat dengan Maslow dalam mengukur motivasi pekerja menurut hirarki kebutuhan. Namun demikian hirarki kebutuhan yang diusulkan hanya terdiri dari tiga peringkat kebutuhan yaitu: Pertama, kebutuhan eksistensi (existence needs) disingkat dengan huruf "E" mencakup seluruh bentuk hasrat material dan fisiologis dengan segala variasinya yaitu, makanan, gaji, dan kondisi kerja. Kedua, kebutuhan hubungan (relatedness needs) diberi lambang huruf " $R$ " yaitu, kebutuhan untuk berhubungan dengan orang lain; rekan kerja, bawahan, atasan atau dengan keluarga dan masyarakat. Ketiga kebutuhan pertumbuhan (growth needs) disingkat dengan huruf "G" yaitu kebutuhankebutuhan yang mendorong seseorang untuk memiliki pengaruh yang kreatif dan produktif terhadap diri sendiri atau lingkungan. Tiga kebutuhan Aldelfer terdapat kesamaan dengan hirarki Maslow misalnya, kebutuhan eksistensi serupa dengan kebutuhan fisiologis dan keamanan dari Maslow, kebutuhan hubungan, serupa dengan kebutuhan sosial (afiliasi), dan kebutuhan pertumbuhan mirip dengan kebutuhan akan penghargaan dan aktualisasi diri.

Kebutuhan untuk prestasi $(n-A c h)$ ini bersifat intrinsik dan relatif stabil (Soekamto, 1994). McCleland (Handoko, 1992) menjelaskan bahwa, orang yang berorientasi pada prestasi mempunyai karakteristik-karakteristik sebagai berikut, 
(1) menyenangi situasi yang menuntut tanggung jawab pribadi untuk pemecahan masalah, (2) cenderung mengambil resiko yang moderat dibanding dengan resiko rendah atau tinggi, dan (3) selalu mengharapkan balikan nyata dapat berupa saran dan kritikan terhadap kinerja yang telah dilakukan. Kebutuhan akan prestasi menurut Winardi (1990) terletak pada hirarki Maslow antara kebutuhankebutuhan penghargaan dan aktualisasi diri. Untuk menumbuhkan motivasi berprestasi yang lebih tinggi, maka perlu diciptakan suatu lingkungan yang kondusif sehingga dapat menyelesai-kan pekerjaan secara baik.

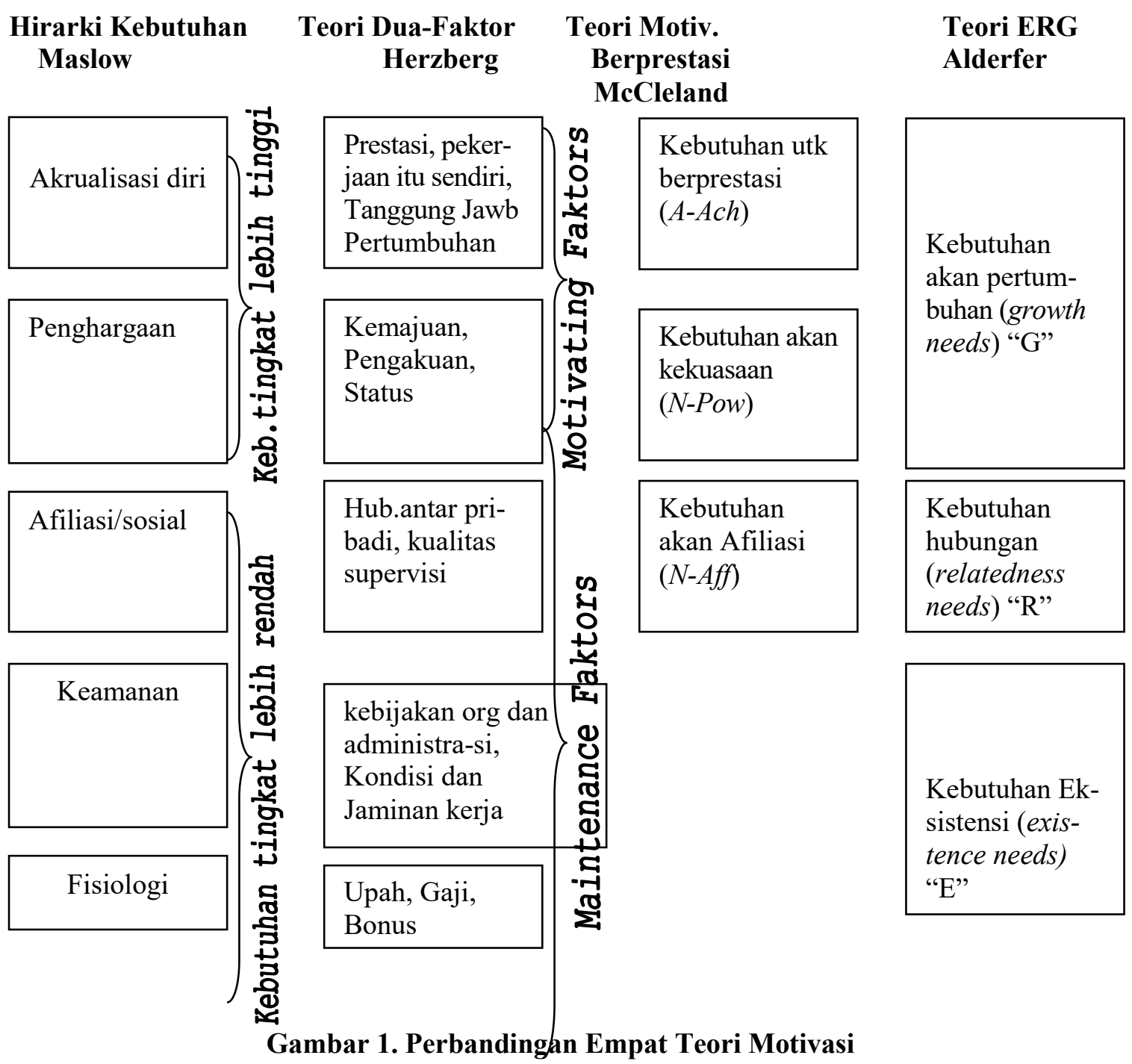

Kebutuhan afiliasi (n-Aff) pada dasarnya identik dengan hirarki afiliasi Maslow. Orang merefleksikan keingin-an untuk memunyai hubungan-hubungan yang harmonis, kooperatif, dan sikap persahabatan dengan pihal lain. Orang yang memiliki kebutuhan afiliasi tinggi, pada umumnya berhasil dalam pekerjaan yang memerlukan interaksi sosial tinggi terutama jenis-jenis pekerjaan yang memerlukan hubungan antar perorangan yang bersifat kritikal bagi hasil pekerjaan.

Kebutuhan akan kekuasaan (n-Pow) merupakan ekspresi dari keinginan 
seseorang individu untuk mengendalikan dan mempengaruhi pihak lain. Kebutuhan akan kekuasaan sangat dekat berhubungan dengan keinginan untuk mencapai suatu posisi kepemimpinan.

\section{Motivasi Berprestasi Siswa}

Jika dicermati secara mendalam, kita dapat menemukan pemahaman mendasar tentang motivasi berprestasi. Jika dilihat dari konsep dasar, motivasi adalah dorongan dasar yang menggerakkan seseorang bertingkah laku. Dorongan ini berada pada diri seseorang yang menggerakkan untuk melakukan sesuatu yang sesuai dengan dorongan dalam dirinya. Oleh karena itu, perbuatan seseorang yang didasarkan atas motivasi tertentu mangandung tema sesuai dengan motivasi yang mendasarinya. Motivasi adalah kekuatan, baik dari dalam maupun dari luar yang mendorong seseorang untuk mencapai tujuan tertentu yang telah ditetapkan sebelumnya.

McClelland menekankan pentingnya kebutuhan berprestasi, karena orang yang berhasil dalam bisnis dan industri adalah orang yang berhasil menyelesaikan segala sesuatu. Ia menandai tiga motivasi utama, yaitu: penggabungan, kekuatan dan prestasi.

Motivasi berprestasi adalah suatu keinginan atau kebutuhan dalam diri seseorang untuk mencapai hasil terbaik. Motivasi berprestasi juga dapat diartikan sebagai kebutuhan untuk menguasai hal-hal yang sulit, menunjukkan kemampuannya pada orang lain dan memeiliki standar yang tinggi untuk melakukan sesuatu. Karakteristik individu yang punya motivasi berprestasi, yaitu: Climber (tipe orang yang pantang menyerah), Campers (tipe orang yang mudah merasa puas dengan apa yang dia miliki selama ini) dan Quitters (tipe orang yang ragu-ragu, pesimis dan tidak mau mengambil resiko). Faktor-faktor yang mempengaruhi motifasi berprestasi, yaitu: faktor lingkungan keluarga dan faktor lingkungan.
Selanjutnya ditampilkan perbe-daan dan kesamaan empat teori motivasi yang dapat menjadi kajian dalam meningkatkan motivasi berprestasi siswa/warga belajar.

Siswa sebagai individu akan belajar dengan baik kalau mereka memiliki motivasi yang tinggi dalam belajarnya. Dengan demikian, motivasi sebagai kondisi yang mempengaruhi, mengarahkan, dan memelihara perilaku untuk penyelesaian tugas-tugas belajar di sekolah. Untuk membangkitkan motivasi berprestasi siswa perlu kondisi dan mengetahui faktor-faktor yang perlu diperhatikan.

Pada dasarnya dalam diri setiap orang terdapat kebutuhan untuk melakukan perbuatan yang bertujuan memperoleh hasil yang sebaik-baiknya. Kebutuhan untuk mencapai

hasil terbaik, oleh David Mc Cleland (dalam Suciati, 1994) disebut kebutuhan untuk berprestasi (need for achievement). Hal ini disadari bahwa sebagian orang mempunyai kualitas tingkatan motivasi berprestasi tinggi, sebagian yang lain tidak, dengan demikian setiap manusia berbeda dalam motivasi berprestasi. Teori motivasi beprestasi (Achievement motivation) dari McCleland mengidentifikasi tiga jenis kebutuhan dasar yaitu, kebutuhan berprestasi ( $n A c h)$, kebutuhan berafiliasi (n-Aff), dan kebutuhan berkuasa ( $n$ Pow).

Kebutuhan untuk berprestasi (nAch) ini bersifat intrinsik dan relatif stabil (Soekamto, 1994). Motivasi disini merupakan fungsi dari tiga variabel, yaitu (1) harapan untuk melakukan tugas dengan berhasil, (2) persepsi tentang nilai tugas dimaksud, (3) kebutuhan untuk keberhasilan atau sukses. Orang yang mempunyai "n-Ach" tinggi ingin menyelesaikan tugas dan meningkatkan penampilan mereka, dan berorientasi kepada tugas dan masalah-masalah yang memberikan tantangan, di mana penampilan mereka dapat dinilai dan dibandingkan dengan suatu patokan/standar atau dibandingkan dengan orang lain. 
Orang dengan "n-Ach" tinggi selalu memilih bekerja untuk tugas-tugas yang penuh tantangan, mereka tidak menyenangi tugas yang mudah dan tidak memberikan tantangan. Dengan demikian terlihat bahwa di dalam melaksanakan tugas mereka tidak bersifat untung-untungan, dan semua tujuan mereka adalah realistis. Apabila berhasil, maka mereka akan cenderung untuk meningkatkan aspirasinya sehingga dapat meningkat ke arah tugas-tugas yang lebih menantang.

McCleland (Handoko, 1992)
menjelaskan bahwa, orang yang berorientasi pada prestasi mempunyai karakteristik-karakteristik sebagai berikut, (1) menyenangi situasi yang menuntut tanggung jawab pribadi untuk pemecahan masalah, (2) cenderung mengambil resiko yang moderat dibanding dengan resiko rendah atau tinggi, dan (3) selalu mengharapkan balikan nyata dapat berupa saran dan kritikan terhadap kinerja yang telah dilakukan. Untuk menumbuhkan motivasi berprestasi yang lebih tinggi, maka perlu diciptakan suatu lingkungan yang kondusif sehingga seseorang dapat menyelesaikan pekerjaan secara baik.

Beberapa penelitian tentang prestasi belajar siswa menunjukkan bahwa motivasi sebagai faktor yang banyak berpengaruh terhadap proses dan hasil belajar siswa. Tokoh-tokoh pendidikan yang bernama Mc Clelland (1985), Bandura (1977), Blomm (1980) melakukan berbagai penelitian tentang motivasi dalam belajar, dan menemukan hasil yang menarik. Sebagai contoh, dalam studi yang dilakukan Fyans dan Maehr (1987) diantara 3 faktor, yaitu: latar belakang keluarga, kondisi//konteks sekolah dan motivasi, faktor yang terakhir merupakan prediktor yang paling baik untuk prestasi belajar. Studi yang dilakukan Suciati (1990) menyimpulkan bahwa kontribusi motivasi sebesar 36 persen, sedangkan Mc Clelland menunjukkan bahwa motivasi berprestasi (achievement motivation) mempunyai kontribusi sa mpai 64 persen terhadap prestasi belajar.
Seorang guru perlu mengetahui sejauh mana kebutuhan siswanya untuk berprestasi, guru diharapkan dapat memanipulasi motivasi, atau memberikan tugas-tugas yang sesuai untuk masingmasing siswa.

Kebutuhan afiliasi (n-Aff) pada dasarnya identik dengan kebutuhan afiliasi Maslow. Orang merefleksikan keinginan untuk mempunyai hubungan-huungan yang harmonis, kooperatif, dan sikap persahabatan dengan pihal lain. Orang yang memiliki kebutuhan afiliasi tinggi, pada umumnya berhasil dalam pekerjaan yang memerlukan interaksi sosial tinggi terutama jenis-jenis pekerjaan yang memerlukan hubungan antar perorangan yang bersifat kritikal bagi hasil pekerjaan.

Kebutuhan akan kekuasaan (nPow) merupakan ekspresi dari keinginan seseorang individu untuk mengendalikan dan mempengaruhi pihak lain. Kebutuhan akan kekuasaan sangat dekat berhubungan dengan keinginan untuk mencapai suatu posisi kepemimpinan.

\section{KESIMPULAN DAN SARAN}

Dalam realitas yang dihadapi, begitu banyak faktor yang mempengaruhi siswa yang sedang melaksanakan kegiatan belajar. Faktor-faktor dominan yang memengaruhi proses belajar antara lain; kemampuan siswa, motivasi, perhatian, persepsi, ingatan, retensi, dan transfer. Dengan demikian motivasi merupakan salah satu faktor yang mempengaruhi proses belajar siswa, karena motivasi merupakan keadaan batin seseorang yang mendorong dan mengarahkan perilaku ke arah tujuan. Seseorang akan termotivasi belajar untuk mencapai sasaran yang dianggap lebih berharga, maka ia akan berusaha secara maksimal demi tercapainya tujuan yang diinginkan. Untuk membangkitkan motivasi berprestasi siswa perlu kondisi yang memungkinkan untuk melakukan aktivitas belajar dengan penuh semangat dan antusias secara terus menerus menambah wawasan dan pengetahuan, baik yang secara langsung berkaitan dengan 
kepentingan dirinya maupun untuk orang lain.

Dalam mengkaji makna belajar, kita dapat menemukan berbagai perspektif yang sangat luas. Bahkan akhir-akhir ini tidak hanya berlandaskan satu aliran tertentu misalnya aliran tingkah laku, aliran kognitif, aliran humanis, atau teori sibernetik akan tetapi lebih bersifat konvergensi (gabungan). belajar adalah suatu proses yang ditandai dengan adanya perubahan pada diri seseorang, perubahan sebagai hasil dari proses belajar dapat ditunjukkan dalam berbagai bentuk seperti berubah pengetahuan, pemahaman, sikap, dan tingkah laku, keterampilan, kecakapan, kebiasaan, serta perubahan aspekaspek lain yang ada pada individu yang belajar. Dari beberapa pendapat mengenai pengertian belajar diatas dapat disimpulkan bahwa belajar adalah adalah kegiatan yang dilakukan oleh seseorang untuk memperoleh pengetahuan, sikap dan keterampilan dengan cara mengolah bahan belajar sehingga terjadi peningkatan pengeta-huan, sikap, dan keterampilan pada diri seseorang yang belajar. Dalam pencapaian perolehan belajar yang diharapkan inilah peran atau esensi motivasi berprestasi sangat besar, karena dorongan untuk mencapai sukses tersebut akan mampu menjadi energi yang tinggi dan mampu mengalahkan berbagai faktor penghambat belajar.
DAFTAR PUSTAKA

Handoko, T.H. (1992). Manajemen. Yogyakarta: Badan Penerbit Fakultas Ekonomi Universitas Indonesia.

Hersey, P. \& Blanchard, K. (1986). Management of Organizational Behavior: Utilizing Human Resources ( $4^{\text {th }}$ Edition). Englewood Cliffs, N. J.: Prentice-Hall, Inc.

Koontz, S., O' Donnel, C. \& Weihrich, H. (1990). Essentials of Management. $\left(5^{\text {th }}\right.$ Ed). New York: Mc-Graw-Hill International Book Company.

Morgan, C. (1986). Introduction to Psychology. Palo Alto C.A. : Fearman Publication. Inc.

Soekamto, T. (1994). Teori Belajar. Jakarta: Depdikbud-Dirjen Dikti, PPAI-PAU Universitas Terbuka.

Stoner. J.A.F. \& Freeman, R.E. (1992). Management. Fifth Edition. Englewood Cliffs, Struktur dan proses. (edisi kedelapan), Alih Bahasa: Nunuk Ardiani, Jakarta:

Suciati. (1994). Teori Motivasi dan penerapannya dalam proses belajarmengajar (ARCS-Model). Jakarta: Depdikbud-Dirjen Dikti, PPAI-PAU Universitas Terbuka.

Winardi. (1990). Asas-asas Manajemen. Bandung: Penerbit Mandar Maju. 